\title{
Minat Menjadi Guru: Persepsi Profesi Guru, Pengenalan Lapangan Persekolahan (PLP) dan Efikasi Diri
}

\author{
Sita Rahmadiyani \\ e-mail:sitarahma1997@gmail.com \\ Lilik Sri Hariani \\ e-mail: liliksrihariani@unikama.ac.id \\ Udik Yudiono \\ e-mail: u_yudiono@unikama.ac.id
}

(Program Studi Pendidikan Ekonomi, Fakultas Ekonomika dan Bisnis, Universitas Kanjuruhan, Malang)

\begin{abstract}
ABSTRAK: Penelitian ini bertujuan untuk mengetahui pengaruh persepsi profesi guru, Pengenalan Lapangan Persekolhan (PLP) dan Efikasi Diri Terhadap Minat Menjadi Guru, baik secara simultan maupun parsial. Penelitian ini menggunakan pendekatan penelitian kuantitatif. Populasi yang digunakan dalam penelitian ini adalah mahasiswa Pendidikan Ekonomi Fakultas Ekonomika dan Bisnis Universitas Kanjuruhan Malang angkatan 2016 dan 2017 dengan jumlah 62 mahasiswa. Sampel dalam penelitian ini dengan mengambil seluruh populasi sebagai sampel penelitian atau dinakaman dengan teknik sampel populasi. Metode pengumpulan data berupa angket atau kuisioner. Metode analisis data yang digunakan dalam penelitian ini adalah analisis regresi linier berganda. Hasil penelitian menunjukkan bahwa secara simultan persepsi profesi guru, Pengenlan Lapangan Persekolahan (PLP) dan efikasi diri berpengaruh terhadap minat menjadi guru. Secara parsial, persepsi profesi guru tidak berpengaruh signifikan terhadap minat menjadi guru. Pengenalan Lapangan Persekolahan (PLP) berpengaruh signifikan terhadap minat menjadi guru. Efikasi diri berpengaruh signifikan terhadap minat menjadi guru.
\end{abstract}

Kata kunci-Profesi, PLP, Efikasi, Minat.

ABSTRACT: This study aims to determine the effect of teacher profession perception, School Field Indroduction (PLP) and Self-Efficacy towards the Interest in Becoming a Teacher, both simultaneously and partially. This research uses a quantitative research approach. The population used in this study were students of Economics and Business Faculty of Economics, Kanjuruhan University Malang class of 2016 and 2017 with a total of 62 students. The sample in this study by taking the entire population as a research sample or funeral with population sample techniques. Data collection methods in the form of questionnaires. The data analysis method used in this study is multiple linear regression analysis. The results showed that, simultaneously teacher profession perception, School Field Indroduction (PLP) and Self-Efficacy effect the interest in becoming a teacher. Partially, the teacher profession perception has not been proven to have a significant effect on interest in becoming a teacher. School Field Indroduction (PLP) has a significant effect on interest in becoming a teacher. Self-efficacy has a significant effect on the interest in becoming a teacher.

Keywords - Profession, PLP, Efficacy, Interest. 


\section{PENDAHULUAN}

Wibowo (2012) menyatakan bahwa pendidikan adalah proses mempersiapkan generasi muda untuk menjalankan kehidupan secara efektif dan efisien. Pemerintah sudah berupaya untuk meningkatakan pendidikan di Indonesia salah satunya dengan adanya pendidikan 12 tahun yang bertujuan agar perserta didik mempunyai kemampuan dasar sebagai bekal kepribadian mereka dalam menghadapi masalah di masa depan. Dalam dunia kependidikan faktor penentu dalam keberhasilan pendidikan adalah tenaga pendidik atau guru. Guru adalah kunci utama untuk membentuk generasi yang berkualitas melalui tugasnya sebagai seorang pendidik.

Menurut Undang-Undang Nomor 14 Tahun 2005 Pasal 1 tentang Guru dan Dosen menjelaskan bahwa Guru adalah merupakan tenaga pendidik professional yang memiliki tugas utama mendidik, mengajar, membimbing, melatih, menilai dan mengevaluasi peserta didik pada pendidikan anak usia dini jalur pendidikan formal, pendidikan dasar dan pendidikan menengah. Seorang guru yang memiliki kualitas baik mampu untuk menciptakan sumber daya manusia yang berkulitas.

Kualitas serta kemamapuan guru dapat dicapai ketika guru atau calon guru mengikuti pendidikan guru. Dimana lembaga pendidikan yang khususnya perguruan tinggi sangatlah berperan penting. Tujuan utama dari perguruan tinggi adalah mampu menciptakan lulusan yang berkualitas, kreatif dan menguasai ilmu-ilmu yang diperlukan sebagai seorang guru. Salah satu yang perlu kita lakukan adalah dengan menciptakan pendidik yang berkualitas dan mampu mencetak generasi penerus untuk memajukan negara. Guru yang profesional harus memiliki kemampuan dan keterampilan yang cakap untuk mendidik seorang siswa, di mana saat ini terdapat Program Profesi Guru (PPG) yang siapapun bisa mengikuti program tersebut. Menurut Peraturan Pemerintah Pendidikan dan Kebudayaan Nomor 87 Tahun 2013 Pasal 6 Ayat 1 tentang Program Pendidikan Profesi Guru Prajabatan menjelaskan bahwa kualifikasi akademik calon peserta didik program PPG dapat diikuti oleh S1 Kependidikan dan S1/DIV Nonkependidikan yang sesuai atau serumpun program pendidikan profesi yang akan ditempuh. Melalui program ini mahasiswa lulusan pendidikan maupun non pendidikan dapat mengikuti program ini dan dapat menjadi seorang guru. Sehingga secara tidak langsung lulusan pendidikan harus mampu bersaing dengan lulusan non pendidikan yang juga ingin menjadi tenaga pendidik. Oleh karena itu, lembaga pendidik ditunut untuk bisa meningkatkan kompetensi yang lebih dari pada mahasiswa non pendidikan. Salah satu cara meningkatkan kompetensi seorang guru yaitu dengan menumbuhkan serta meningkatkan minat mereka untuk menjadi seorang guru yang professional.

Menurut Slameto (2010:180) minat merupakan rasa senang terhadap sesuatu yang ada dalam diri seseorang tanpa ada pengaruh orang lain. Menurut teori tersebut dapat dikatakan bahwa pada dasarnya minat akan tumbuh dalam diri kita dengan sendirinya tanpa adanya pengaruh dari orang lain yang ada di sekitar kita. Jika dikaitkan dengan minat menjadi seorang guru, tentunya seseorang yang memiliki minat menjadi seorang guru akan merasa senang dengan pekerjaan sebagai seorang guru tanpa ada yang menyuruhnya dan akan berusaha untuk meningkatakna kualitasnya sebagai calon guru yang profesional. Hal ini akan dapat meningkatkan minat mahasiswa untuk menjadi seorang guru. Namun dalam kenyataannya, beberapa mahasiswa program studi kependidikan memiliki alasan untuk mengambil program studi ini dikarenakan saran dari orangtua, pengaruh teman ataupun karena keluaran atau lulusan dari program studi kependidikan yang bisa kerja dalam dua bidang yaitu bidang kependidikan ataupun diluar kependidikan. Dalam hal ini, setiap mahasiswa yang menempuh kuliah di program studi kependidikan belum tentu dalam dirinya memiliki minat menjadi guru. 
Program Studi Pendidikan Ekonomi Universitas Kanjuruhan Malang bertujuan untuk menciptakan dan mempersiapkan lulusannya untuk menjadi guru profesional. Namun dalam kenyataanya, tidak semua lulusan dari program studi Pendidikan Ekonomi berprofesi sebagai seorang guru. Hasil data tracer study Prodi Pendidikan Ekonomi tahun 2017 dan 2018 menunjukkan bahwa lulusan Pendidikan Ekonomi Universitas Kanjuruhan Malang yang berprofesi sebagai guru (Instansi Pemerintah) pada tahun 2017 dan 2018 sejumlah 21\% dan 7\%, sisanya berprofesi non guru seperti wiraswasta atau perusahaan sendiri, dan lainnya. Hal ini dijadikan sebagai indikasi bahwa minat mahasiswa Pendidikan Ekonomi menjadi seorang guru masih rendah.

Menurut Sardiman (2012:89-91) terdapat dua faktor yang dapat mempengaruhi minat seseorang yaitu faktor intrinsik dan faktor ekstrinsik. Minat mahasiswa menjadi guru dipengaruhi oleh beberapa variabel seperti lingkungan keluarga, persepsi profesi guru, Pengenalan Lapangan Persekolahan (PLP), teman bergaul, informasi dunia kerja, kesejahteraan guru, efikasi diri ataupun kepribadian diri. Dari variabel-variabel ini, peneliti menduga beberapa variabel yang dapat mempengaruhi minat mahsiswa menjadi seorang guru yang dapat digunakan dalam penelitian ini adalah persepsi profesi guru, Pengenalan Lapangan Persekolahan (PLP) dan efikasi diri.

Penelitian oleh Ardyani dan Latifa (2014) tentang analisis faktor-faktor yang mempengaruhi minat mahasiswa menjadi guru. Hasil penelitian ini menunjukkan bahwa terdapat tujuh faktor yang dapat mempengaruhi minat mahasiswa menjadi seorang guru yaitu persepsi mahasiswa tentang profesi guru, kesejahteraan guru, prestasi belajar, pengalaman PPL, teman bergaul lingkungan keluarga dan kepribadian.

Kuswana (2011:220) menyatakan bahwa persepsi merupakan proses mengatur dan mengintepretasikan kesan-kesan sensoris seseorang yang dapat memberikan arti bagi orang. Setiap mahasiswa tentunya memiliki persepsi tersendiri tentang profesi guru. Persepsi tentang profesi guru pada diri mahasiswa dapat menimbulkan rasa suka dan tidak suka terhadapa profesi guru, dan hal tersebut akan mempengaruhi minat mahasiswa untuk menjadi seorang guru. Persepsi mahasiwa yang positif tentang profesi guru akan dapat menimbulkan minat mahasiswa untuk menjadi guru tinggi, sebaliknya persepsi mahasiswa yang negatif tentang profesi guru akan menimbulkan minat mahasiswa untuk menjadi guru rendah.

Penelitian terdahulu yang dilakukan oleh Mulyono dan Waluyo (2016), hasil penelitian ini menunjukkan bahwa persepsi profesi guru berpengaruh signifikan terhadap minat menjadi guru. Penelitian oleh Wahyuni dan Setyani (2017), hasil penelitian menunjukkan persepsi tentang profesi guru tidak berpengaruh terhadap minat menjadi guru.

Buku Pedoman PLP Unikama (2019:6) menyatakan bahwa PLP adalah tahapan dalam penyiapan calon guru professional pada jenjang Program Sarjana Pendidikan, yang berupa penugasan kepada mahasiswa dalam mengimplementasikan hasil belajar melalui pengamatan proses pembelajaran, pengembangan perangkat pembelajaran dan belajar mengajar terbimbing di sekolah. PLP dilaksanakan dengan maksud agar mahasiswa sebagai calon pendidik dapat mengerti, memhami dan memilki kemampuan kritis terhadap profesi seorang guru. dimaksudkan agar dari sedini mungkin calon pendidik memahami, mengetahui, menghayati, menjiwai dan memiliki kemampuan kritis dan analitis terhadap profesinya menjadi seorang guru. Program PLP bertujuan untuk melatih serta mengembangkan kemampuan dan keterampilan mahasiswa dalam mengimplementasikan ilmu sebagai seorang guru dengan berhuhubungan langsung di lembaga sekolah. Dengan adanya program PLP, mahasiswa akan mengetahui tugas, kewajiban dan 
tanggungjawab seorang guru. Dari pengetahuan dan pengalaman mahasiswa melaksanakan program PLP, maka hal ini akan dapat mempengaruhi tingkat minat mahasiswa untuk menjadi seorang guru.

Penelitian terdahulu oleh Hidayat (2017) dengan hasil terdapat pengaruh antara program pengalaman lapangan terhadap minat menjadi guru. Penelitian lain juga dilakukan oleh Wahyu (2019) yang menunjukkan bahwa pengalaman kajian dan praktik lapangan tidak berpengaruh terhadap minat menjadi guru. Penelitian lain oleh Sari, Martono dan Wahyuni (2017) dengan hasil yang menujukkan bahwaterdapat pengaruh antara program pengalaman lapangan terhadap minat menjadi guru.

Faktor lain yang dapat mempengaruhi minat mahasiswa untuk menjadi guru adalah efikasi diri. King (2012:153) menjelaskan bahwa efikasi diri adalah keyakinan yang dimiliki seseorang untuk dapat menguasai suatu keadaan dan menghasilkan hal-hal positif. Efikasi diri yaitu keyakianan yang dimiliki setiap individu atas kemampuannya dalam melaksankan tugas atau suatu pekerjaan. Setiap orang memiliki efikasi diri atau keyakinan terhadap dirinya yang berbeda-beda tergantung pada kemampuan yang menuntut, kehadiran orang atau saingan yang ada di sekitarnya. Keyakianan terhadapa kemampuan yang dimilki mahasiswa tentang profesi guru akan dapat mempengaruhi minat mahasiswa untuk menjadi seorang guru. Semakin tinggi tingkat keyakinan mahasiswa tentang kemampuannya maka semakin tinggi pula minat yang dimiliki mahasiswa untuk menjadi seorang guru. Begitu sebaliknya, semakin rendah tingkat keyakinan mahasiswa atas kemampuan yang dimilkinya maka semakin rendah pula minat yang dimiliki mahasiswa untuk menjadi seorang guru. Penelitian terdahulu yang dilakukan oleh Aini (2018) dengan hasil yang menunjukkan bahwa efikasi diri berpengaruh signifikan terhadap minat menjadi guru.

Penelitian-penelitian terdahulu secara internasional yang berhubungan dengan penelitian ini antara lain penelitian yang dilakukan oleh Altay Eren (2012) tentang Prospective Teachers' Interest in Teaching, Professional Plans about Teaching and Career Choice Satisfaction: A Relevant Framewok. Penelitian yang dilakukan oleh Ulrika Bergmark, Stefan Lundstrom, Lena Manderstedt and Annbritt Palo (2018) tentang Why Become A Teacher? Student Teachers' Perceptions of the Teaching Profession and Motives for Career Choice. Penelitian yang dilakukan oleh Genevieve Aglazor (2017) tentang The Role of Teaching Practice in Teacher Education Programmers: Designing Framework for Best Practice. Penelitian yang dilakukan oleh Catherine M. Aurah (2013) tentang The Effects of Self-Efficacy Beliefs and Metacognition on Academic Performance: A Mixed Method Study. Penelitian yang dilakukan oleh Nenty, H.J., Moyo, Sello dan Phuti, Fuji (2015) tentang The Effects of Self-Efficacy Beliefs and Metacognition on Academic Performance: A Mixed Method Study.

Berdasarkan latar belakang diatas mendorong peneliti untuk melakukan penelitian dengan judul "Persepsi Prosesi Guru, Pengenalan Lapangan Persekolahan (PLP) dan Efikasi Diri Terhadap Minat Menjadi Guru". Penelitian ini bertujuan: 1) Untuk mengetahui pengaruh secara simultan persepsi profesi guru, Pengenalan Lapangan Persekolahan (PLP) dan efikasi diri terhadap minat menjadi guru, 2) Untuk mengetahui pengaruh secara parsial persepsi profesi guru terhadap minat menjadi guru, 3) Untuk mengetahui pengaruh secara parsial Pengenalan Lapangan Persekolahan (PLP) terhadap minat menjadi guru, 4) Untuk mengetahui pengaruh secara parsial efikasi diri terhadap minat menjadi guru. 


\section{TINJAUAN PUSTAKA}

Jahja (2011:63) menyatakan bahwa minat adalah dorongan yang dimiliki seseorang yang berupa perhatian terhadap suatu ojek seperti pekerjaan, pelajaran, benda dan orang. Minat seseorang biasanya berhubungan dengan beberapa aspek yaitu aspek kognitif, afektif dan psikomotorik. Minat sebagai sumber motivasi seseorang untuk melakukan suatu kegiatan atau pekerjaan sesuai keinginannya. Guru adalah sebuah profesi atau jabatan yang memerlukan keahlian dan keterampilan khusus serta tidak dapat dilakukan oleh sembarang orang yang tidak mempunyai pengetahuan dan keterampilan di bidang peniddikan. Menurut Syah (2013:257) guru adalah seseorang yang bekerja sebagai tenaga pendidik yang bertugas mengajar, dalam arti mengembangkan ranah cipta, rasa dan karsa siswa sebagai implementasi konsep ideal mendidik yang dilakukan di dunia pendidikan. Minat menjadi seorang guru merupakan perasaan senang dan tertarik untuk mejalankan tugas sebagai seorang guru yang kemudian ketertarikan itu akan berubah menjadi perhatian lebih terhadap profesi seorang guru. Minat seseorang untuk menjadi guru dapat timbul dari beberapa hal seperti tanggapan baik dalam diri individu, pengalaman dan keberadaan profesi guru yang dipandang dari sudut individu itu sendiri.

Kuswana (2011:220) menyatakan "persepsi merupakan proses saat seseorang mengatur dan menginterpretasikan kesan-kesan sensoris mereka guna memberikan arti bagi lingkungan mereka". Persepsi timbul karena perilaku individu tanpa melihat kenyataan sebenarnya. Menurut Wiyani (2015:56) profesi adalah pekerjaan seseorang atau sekelompok orang yang membutuhkan bekal pengetahuan, keahlian dan keterampilan sesuai dengan. Persepsi profesi guru merupakan suatu penialaian atau pandangan seseorang tentang profesi atau pekerjaan sebagai seorang guru.

Pengenalan Lapangan Persekolahan (PLP) adalah suatu mata kuliah yang diperuntukkan untuk melatih mahasiswa dalam mengimplementasikan hasil belajar di kampus untuk diterapkan secara langsung di lembaga pendidikan jatau sekolah. PLP merupakan suatu program yang bertujuan membentuk dan membina mahasiswa untuk menguasai pengetahuan dan keterampilan yang berhubungan dengan kompetensi seorang guru dan dilakukan di lembaga pendidikan. Hamalik (2011:171-172) menjelaskan bahwa sasaran dalam program praktikmengajar atau PLP adalah tercapainya kepribadian calon pendidik yang mempunyai pengetahuan dan keterampilan seorang guru serta dapat menggunakannya secara tepat dalam penyelenggaran proses pengajaran di dalam maupun luar lembaga pendidikan atau sekolah. Pelaksanaan PLP berpegang pada UndangUndang Guru dan Dosen Nomor 14 Tahun 2005. Buku Pedoman PLP UNikama (2019:1) menyatakan "Pasal 8 guru menyatakan bahwa wajib memiliki kualifikasi akademik, kompetensi, sertifikasi pendidik, sehat jasmani dan rohani serta kemampuan kemempuan untuk mewujudkan tujuan pendidikan nasional". Berdasarkan hal yang telah dijelaskan tersebut, terdapat empat kompetensi yang harus dimiliki oleh seorang guru yaitu kompetensi pedagogik, kompetensi kepribadian, kompetensi profesional dan kompetensi sosial (Mulyasa, 2011:75).

King (2012:153) menyatakan bahwa "efikasi diri adalah keyakinan bahwa seseorang dapat menguasai suatu situasi dan menghasilkan berbagai hal positif". Efikasi diri (Self efficacy) merupakan keyakianan yang dimiliki oleh seseorang mengenai kemampuan dalam dirinya untuk memahami atau melakuakn suatu hal. Menurut Ormrod (2011:20) self efficacy atau efikasi diri adalah penilaian seseorang tentang kemampuan yang dimilikinya dalam menjalankan tugas tertentuk untuk mencapai tujuan yang telah ditentukan. Efikasi diri berhubungan dengan kepercayaan seseorang untuk melaksanakan sebuah tugas dengan benar dan sesuai dengan yang diharapkan. Efikasi diri adalah kepercayaan atau keyakinan yang dimiliki oleh seseorang mengenai kemampuan yang dimilikinya dalam mengerjakan atau melaksanakan sebuah tantangan atau tugas guna mencapai hasil yang diinginkan. 


\section{METODE}

Penelitian ini menggunkan pendekatan penelitian kuantitatif. Populasi yang digunakan dalam penelitian ini adalah mahasiswa Program Studi Pendidikan Ekonomi Fakultas Ekonomika dan Bisnis Universitas Kanjuruhan Malang angkatan 2016 dan 2017 sebanyak 62 mahasiswa. Dari jumlah populasi yang ada, peneliti mengambil sampel sebanyak 62 mahasiswa. Teknik pengambilan sampel dalam penelitian ini menggunakan teknik sampel jenuh atau sampel populasi dikarenakan jumlah populasinya kurang dari 100. Variabel terikat yang digunakan yaitu minat menjadi guru, sedangkan variabel bebas yang digunakan yaitu persepsi profesi guru, Pengenalan Lapangan Persekolahan (PLP) dan efikasi diri.

Variabel minat menjadi guru dapat di ukur oleh bebrapa indikator yakni kognisi (mengenal), asumsi (perasaan) dan konasi (kehendak). Variabel persepsi profesi guru dapat diukur dengan indikator yakni persepsi mahasiswa tentang peran guru, persepsi mahasiswa tentang kompetensi yang dimilki guru, persepsi mahasiswa tentang profesi guru di masyarakat, persepsi mahasiswa tentang hak-hak finasial guru dan persepsi mahasiswa tentang kewajiban guru. Variabel Pengenalan Lapangan Persekolahan (PLP) dapat diukur dengan indikator yakni kompetensi pedagogik, kompetensi kepribadian, kompetensi profesional dan kompetensi sosial. Variabel efikasi diri dapat di ukur dengan beberapa indikator yakni tingkat (level), kekuatan (strength) dan generalisasi (generality).

Metode prngumpulan data berupa angket atau kuisioner. Validitas dan reliabilitas data diperoleh melalui uji coba dari 30 responden yang disebar pada mahasiswa di luar sampel. Penelitian ini menggunakan metode analisis regresi linier berganda dan dilakukan pengujian hipotesis dengan sebelumnya dilakukan uji prasyarat regresi linier berganda yaitu uji asumsi klasik. Dalam pengujian analisis data hasil dari penyebaran angket, peneliti menganalisis dengan menggunakan program SPSS 22.00 for windows.

\section{PEMBAHASAN}

Penelitian ini terdiri dari tiga variabel bebas yaitu persepsi profesi guru, Pengenalan Lapangan Persekolahan (PLP) dan efikasi diri yang berpengaruh terhadap minat menjadi guru pada mahasiswa Prodi Pendidikan Ekonomi Universitas Kanjuruhan Malang angkatan 2016 dan 2017. Berikut ini adalah tabel deskriptif variabel hasil dari analisis statistik deskriptif yang diperoleh dari data dengan instrument penelitian skala likert pada Tabel 1 sebagai berikut:

Tabel 1. Statistik Deskriptif

\begin{tabular}{|c|c|c|c|c|c|}
\hline \multicolumn{6}{|c|}{ Statistics } \\
\hline & & $\begin{array}{l}\text { (Minat Menjadi } \\
\text { Guru) }\end{array}$ & $\begin{array}{l}\text { (Persepsi Profesi } \\
\text { Guru) }\end{array}$ & $\begin{array}{c}\text { (Pengenalan Lapangan } \\
\text { Persekolahan (PLP)) }\end{array}$ & $\begin{array}{l}\text { (Efikasi } \\
\text { Diri) }\end{array}$ \\
\hline \multirow[t]{2}{*}{$\bar{N}$} & Valid & 62 & 62 & 62 & 62 \\
\hline & Missing & 0 & 0 & 0 & 0 \\
\hline \multicolumn{2}{|c|}{ Mean } & 50.52 & 42.94 & 80.61 & 73.58 \\
\hline \multicolumn{2}{|c|}{ Median } & 52.00 & 43.00 & 84.00 & 74.00 \\
\hline \multicolumn{2}{|c|}{ Minimum } & 23 & 35 & 59 & 57 \\
\hline \multicolumn{2}{|c|}{ Maximum } & 64 & 48 & 89 & 88 \\
\hline \multicolumn{2}{|c|}{ Sum } & 3132 & 2662 & 4998 & 4562 \\
\hline
\end{tabular}

Berdasarkan Tabel 1. Diketahui bahwa untuk variabel minat menjadi guru yang diperoleh dari 62 reponden dengan rincian 13 soal yang telah dianalisis dinyatakan data valid (sah untuk diproses) dan data yang hilang (missing) adalah nol, nilai rata-rata 50,52, nilai minimumnya 23 dan 
nilai maksimum 64, dengan demikian minat menjadi guru berada pada kategori tinggi. Untuk variabel persepsi profesi guru yang diperoleh dari 62 responden dengan rincian 10 soal yang telah dianalisis dinyatakan data valid (sah untuk diproses) dan data yang hilang (missing) adalah nol, nilai rata-rata 42,94, nilai minimumnya 35 dan nilai maksimum 48, dengan demikian persepsi profesi guru berada pada kategori baik. Untuk variabel Pengenalan Lapangan Persekolahan (PLP) yang diperoleh dari 62 reponden dengan rincian 19 soal yang telah dianalisis dinyatakan data valid (sah untuk diproses) dan data yang hilang (missing) adalah nol, nilai rata-rata 80,61, nilai minimumnya 59 dan nilai maksimum 89, dengan demikian Pengenalan Lapangan Persekolahan (PLP) berada pada kategori baik. Untuk variabel efikasi diri yang diperoleh dari 62 reponden dengan rincian 18 soal yang telah dianalisis dinyatakan data valid (sah untuk diproses) dan data yang hilang (missing) adalah nol, nilai rata-rata 73,58, nilai minimumnya 57 dan nilai maksimum 88, dengan demikian efikasi diri berada pada kategori tinggi.

Sebelum melakukan analisis regresi linier berganda dan pengujian hipotesis, dilakukan uji prasyarat analisis yaitu yaitu melalui uji asumsi klasik yang terdiri dari uji normalitas, uji multikolinearitas, uji heteroskedastisitas dan uji autokorelasi. Hasil analisis uji normalitas yang diperoleh menggunakan grafik normal plot dapat disimpulkan bahwa penyebaran data berada di sekitar garis diagonal serta penyebarannya mengikuti arah garis diagnolnya, sehingga menunjukkan bahwa data berdistribusi secara normal. Selanjutnya yaitu melakukan uji multikolinearitas dengan hasil analisis yang menunjukkan bahwa pada variabel persepsi profesi guru nilai VIF sebesar 1,371< 5 berarti variabel tersebut tidak berkorelasi sempurna, variabel Penegenalan Lapangan Persekolahan (PLP) nilai VIF sebesar 1, $478<5$ berarti variabel tersebut tidak berkorelasi sempurna dan variabel efikasi diri nilai VIF sebesar $1,419<5$ berarti variabel tersebut tidak berkorelasi sempurna, dengan begitu dapat disimpulkan bahwa ketiga variabel dinyatakan tidak terdapat gejala multikolinearitas dalam model regresi ini.

Hasil uji heteroskedasitas yang diperoleh menggunakan grafik scatterplot dengan hasil data menyebar secara acak atau tidak membentuk suatu pola tertentu, dengan begitu hasil analisis menyatakan bahwa tidak terdapat gejala heteroskedatisitas dalam model regresi ini. Sedangkan hasil uji autokorelasi yang menunjukkan bahwa besar nilai Durbin Watson adalah 1,666. Pada nilai ini, berarti hasil nilai durbit Watson antara -2 sampai +2 yang artinya tidak ada atau bebas dari gejala autokorelasi dalam model regresi ini.

Setelah dilakukannya uji asumsi klasi kemuadian dian dialkukan analysis regresi linier berganda dengan hasil pada Tabel 2 sebagai berikut:

Tabel 2. Hasil Analisis Regresi Linier Berganda

Coefficients $^{a}$

\begin{tabular}{|c|c|c|c|c|c|}
\hline \multirow{3}{*}{\multicolumn{2}{|c|}{ Model }} & \multirow{2}{*}{\multicolumn{2}{|c|}{$\begin{array}{c}\text { Unstandardized } \\
\text { Coefficients }\end{array}$}} & \multirow{3}{*}{$\mathrm{T}$} & \multirow{3}{*}{ Sig. } \\
\hline & & & & & \\
\hline & & B & Std. Error & & \\
\hline \multirow[t]{4}{*}{1} & (Constant) & -24.053 & 11.718 & -2.053 & .045 \\
\hline & Persepsi Profesi Guru & .141 & .278 & .506 & .615 \\
\hline & $\begin{array}{l}\text { Pengenalan Lapangan } \\
\text { Persekolahan (PLP) }\end{array}$ & .396 & .134 & 2.953 & .005 \\
\hline & Efikasi Diri & .497 & .140 & 3.538 & .001 \\
\hline
\end{tabular}

Berdasarkan Tabel 2. menunjukkan hasil regresi sebagai berikut :

$\mathrm{Y}=-24,053+0,141 \mathrm{X} 1+0,369 \mathrm{X} 2+0,497 \mathrm{X} 3$ 
Persamaan hasil analisis regresi linier berganda tersebut mengandung arti bahwa: (1) konstanta sebesar -24,053 artinya jika variabel persepsi profesi guru (X1), Pengenalan Lapangan Persekolahan (PLP) (X2) dan efikasi diri (X3) nilainya adalah 0, maka minat menjadi guru (Y) nilainya sebesar -24,053. (2) Koefisien regresi variabel persepsi profesi guru (X1) 0,141; artinya jika variabel persepsi profesi guru (X1) mengalami kenaikan 1 satuan, maka minat menjadi guru (Y) akan mengalami kenaikan sebesar 0,141. Koefisien bernilai positif maka pengaruhnya searah dan berhubungan positif. (3) Koefisien regresi variabel Pengenalan Lapangan Persekolahan (PLP) (X2) 0,369; artinya jika variabel Pengenalan Lapangan Persekolahan (PLP) (X2) mengalami kenaikan 1 satuan, maka minat menjadi guru (Y) akan mengalami kenaikan sebesar 0,369. Koefisien bernilai positif maka pengaruhnya searah dan berhubungan positif. (4) Koefisien regresi variabel efikasi diri (X3) 0, 497 artinya jika variabel efikasi diri (X3) mengalami kenaikan 1 satuan, maka minat menjadi guru (Y) akan mengalami kenaikan sebesar 0,497. Koefisien bernilai positif maka pengaruhnya searah dan berhubungan positif.

Tabel 3. Hasil Uji F (Uji Secara Simultan)

ANOVA $^{\mathrm{a}}$

\begin{tabular}{llrrrrr}
\hline & Model & \multicolumn{1}{c}{$\begin{array}{l}\text { Sum of } \\
\text { Squares }\end{array}$} & Df & Mean Square & \multicolumn{1}{c}{ F } & \multicolumn{1}{c}{ Sig. } \\
\hline 1 & Regression & 2009.979 & 3 & 669.993 & 16.696 & $.000^{\mathrm{b}}$ \\
& Residual & 2327.505 & 58 & 40.129 & & \\
& Total & 4337.484 & 61 & & & \\
\hline
\end{tabular}

Berdasarkan Tabel 3 menunjukkan besarnya nilai Fhitung adalah 16,696 > Ftabel 2,76 dan nilai signifikasi $0,000<0,05$, maka dapat disimpulkan bahwa H0 ditolak dan H1 diterima artinya penelitian persepsi profesi guru, Pengenalan Lapangan Persekolahan (PLP) dan efikasi diri secara bersama-sama (simultan) berpengaruh signifikan terhadap minat menjadi guru pada mahasiswa Prodi Pendidikan Ekonomi Universeitas Kanjuruhan Malang angkatan 2016 dan 2017.

Tabel 4. Hasil Uji t (Uji Secara Parsial)

Coefficients $^{\mathrm{a}}$

\begin{tabular}{llccc}
\hline \multicolumn{1}{c}{ Model } & T & Sig. & Keterangan \\
\hline 1 & (Constant) & -2.053 & .045 & \\
& Persepsi Profesi Guru & .506 & .615 & Tidak Signifikan \\
Pengenalan Lapangan & 2.953 & .005 & Signifikan \\
Persekolahan (PLP) & 3.538 & .001 & Signifikan \\
Efikasi Diri & & & \\
\hline
\end{tabular}

Berdasarkan tabel 4 yang menunjukkan bahwa hasil uji parsial (uji t) untuk variabel persepsi profesi guru, Pengenalan Lapangan Persekolahan (PLP) dan efikasi diri sebagai berikut. (1) variabel persepsi profesi guru (X1) tidak berpengaruh yang signifikan. Hal tersebut dapat dilihat dari nilai thitung sebesar 0,506 < ttabel sebesar 2,001 dan nilai signifikasi sebesar 0,615 $<0,05$, sehingga H0 diterima dan $\mathrm{H} 2$ ditolak maka dapat diartikan bahwa secara parsial persepsi profesi guru terbukti tidak berpengaruh yang signifikan terhadap minat menjadi guru. (2) variabel Pengenalan Lapangan Persekolahan (PLP) (X2) berpengaruh yang signifikan. Hal tersebut dapat dilihat dari besarnya nilai thitung yaitu 0,953 > ttabel sebesar 2,001 dan nilai signifikasi sebesar 0,005 < 0,05, sehingga H0 ditolak dan H3 diterima artinya secara parsial Pengenalan Lapangan Persekolahan (PLP) berpengaruh yang signifikan terhadap minat menjadi guru. (3) variabel efikasi diri (X3) berpengaruh 
yang signifikan. Hal tersebut dapat dilihat dari besarnya nilai thitung yaitu $0,538>$ ttabel sebesar 2,001 dan nilai signifikasi sebesar 0,001 < 0,05, sehingga H0 ditolak dan H4 diterima maka dapat diartikan bahwa secara parsial efikasi diri berpengaruh yang signifikan terhadap minat menjadi guru.

Tabel 5. Hasil Uji R2 (Koefisien Determinasi)

Model Summary

\begin{tabular}{lrrrr}
\hline Model & $\mathrm{R}$ & R Square & Adjust R Square & Std. Error of the Estimate \\
\hline 1 & $.681^{\mathrm{a}}$ & .463 & .436 & 6.335 \\
\hline
\end{tabular}

Berdasarkan Tabel 5 diketahui bahwa besar nilai R square adalah 0,463, yang berarti variabel persepsi profesi guru, Pengenalan Lapangan Persekolahan (PLP) dan efikasi diri memiliki pengaruh terhadap minat menjadi guru sebesar $46,3 \%$. Sedangkan sisanya sebesar $53,7 \%$ dipengaruhi oleh variabel lain yang tidak terdapat dalam penelitian ini.

\section{Pengaruh Persepsi Profesi Guru, Pengenalan Lapangan Persekolahan (PLP) dan Efikasi Diri Terhadap Minat Menjadi Guru}

Berdasarkan hasil uji F yang menunjukkan bahwa nilai Fhitung sebesar 16,696 > Ftabel sebesar 2,76 dengan nilai signifikan 0,000 $<0,05$, maka $\mathrm{H}_{01}$ ditolak dan $\mathrm{H}_{a 1}$ diterima, sehingga terdapat pengaruh secara simultan antara persepsi profesi guru, Pengenalan Lapangan Persekolahan (PLP) dan efikasi diri berpengaruh terhadap minat menjadi guru pada mahasiswa Prodi Pendidikan Ekonomi Universitas Kanjuruhan Malang angkatan 2016 dan 2017. Koefisien determinasi ( $\left.R^{2}\right)$ dengan nilai Adjusted $R$ Square sebesar 0,436 yang artinya persepsi profesi guru, Pengenalan Lapangan Persekolahan (PLP) dan efikasi diri memberikan kontribusi sebesar 43,6\% terhadap minat menjadi guru dan sisanya sebesar $56,4 \%$ dipengaruhi oleh variabel lain yang tidak terdapat dalam penelitian ini seperti lingkungan keluarga, teman bergaul, informasi dunia kerja, kesejahteraan guru ataupun kepribadian diri.

Koefisien determinasi (R2) sebesar 43,6\% mempunyai makna bahwa ketiga variabel independen yaitu persepsi profesi guru, Pengenalan Lapangan Persekolahan (PLP) dan efikasi diri memberikan kontribusi terhadap minat menjadi guru pada mahasiswa Prodi Pendidikan Ekonomi dikarenakan adanya persepsi yang baik terhadap profesi guru, program Pengenalan Lapangan Persekolahan (PLP) memberikan pengalaman yang baik kepada mahasiswa, serta tingkat efikasi diri atau keyakinan diri mahasiswa yang tinggi bahwa ia mampu berprofesi sebagai guru dengan baik. Dengan adanya persepsi yang baik mengenai profesi guru akan dapat menimbulkan minat mahasiswa Pendidikan Ekonomi untuk memilih karir sebagai seorang guru. Mahasiswa yang memiliki persepsi baik tentunya akan memilki ketertarikan terhadap profesi guru yang bisa diwujudkan dengan menambah pengetahuan, keterampilan dan kemampuan sebagai seorang guru. Selain persepsi yang baik mengenai profesi guru, pengalaman yang diperoleh selama program Pengenalan Lapangan Persekolahan (PLP) juga dapat mempengaruhi minat karena dengan adanya pengalaman yang baik mahasiswa dapat mengimplementasikan kemampuannya sebagai seoorang guru secara langsung dengan baik dan benar sehingga akan dapat mempengaruhi minat mahasiswa untuk menjadi guru. Efikasi diri atau keyakinan yang tinggi mengenai kemampuan yang dimiliki oleh mahasiswa mengenai tugas sebagai profesi guru akan mempengaruhi minat mahasiswa karena mereka merasa yakin dengan dapat melaksanakan segala tugas dan tanggng jawab yang dimilki seorang guru. Semakin tinggi tingkat efikasi diri yang dimiliki mahasiswa maka minat mahasiswa untuk menjadi seorang guru juga akan semakin tinggi. 
Berdasarkan besarnya koefisien determinasi (R2) sebesar 46,3\% dapat disimpulkan bahwa kontribusi variabel independen pada minat mahasiswa untuk menjadi seorang guru tergolong cukup rendah yang artinya minat mahasiswa untuk menjadi seorang guru tidak hanya dipengaruhi oleh persepsi profesi guru, Pengenalan Lapangan Persekolahan (PLP) dan efikasi diri. Minat mahasiswa menjadi guru juga dapat dipengaruhi oleh variabel lain seperti teman bergaul. Hal ini sesuai dengan penelitian yang dilakukan oleh Ardyani (2014) tentang Analisis Faktor-Faktor yang Mempengaruhi Minat Mahasiswa Untuk Menjadi Guru Akuntansi Pada Mahasiswa yang menunjukkan bahwa terdapat pengaruh antara teman bergaul terhadap minat menjadi guru.

\section{Pengaruh Persepsi Profesi Guru Terhadap Minat Menjadi Guru}

Berdasarkan hasil uji t menunjukkan bahwa nilai thitung sebesar 0,506 < tabel sebesar 2,001 dan nilai signifikasi sesbesar 0,615 $>$ 0,05, maka $\mathrm{H}_{02}$ diterima dan $\mathrm{H}_{a 1}$ ditolak. Artinya hipotesis yang menyatakan bahawa persepsi profesi guru tidak berpengaruh terhadap minat menjadi guru ini diterima dan hipotesis yang menyatakan bahwa persepsi profesi guru berpengaruh terhadap minat menjadi guru ditolak karena persepsi profesi guru hanya sebatas penilaian mahasiswa Prodi Pendidikan Ekonomi mengenai profesi guru dan tidak menjadikan mahasiswa Prodi Pendidikan Ekonomi memiliki keinginan untuk menjadi seorang guru. Koefisien determinasi parsial menunjukkan nilai 0,066 atau $0,44 \%$. Artinya bahwa persepsi profesi guru tidak terbukti berpengaruh sebesar $0,44 \%$ terhadap minat menjadi guru pada mahasiswa Prodi Pendidikan Ekonomi Universitas Kanjuruhan Malang angkatan 2016 dan 2017.

Hal ini tidak sesuai dengan hipotesis penelitian yang dibuat peneliti yaitu terdapat pengaruh persepsi profesi guru terhadap minat menjadi guru . Dengan demikian, persepsi profesi guru tidak berpengaruh terhadap minat menjadi guru yang artinya semakin baik (positif) persepsi mahasiswa mengenai profesi guru tidak akan berpengaruh terhadap minat mahasiswa untuk menjadi guru. Begitu pula sebaliknya persepsi mahasiswa tentang profesi guru yang buruk (negatif) juga tidak berpengaruh terhadap minat menjadi seorang guru. Hal ini dimungkinkan karena persepsi profesi guru hanya sebatas cara pandang dan penilaian mahasiswa tentang profesi guru, sehingga tidak mempengaruhi dan tidak mendorong mahasiswa untuk berprofesi sebagai seorang guru.

Persepsi merupakan penilaian atau pandangan seseorang mengenai suatu hal yang artinya setiap orang memiliki penilaian dan pandangan tersendiri. Persepsi profesi guru berisi penilaian mahasiswa tentang profesi guru, dimana penilaian mahasiwa mengenai profesi guru ini tidak berarti bahwa mahasiswa tersebut memilki minat untuk menjadi seorang guru. Mahasiswa yang memilki persepsi baik mengenai profesi guru bukan berarti dalam dirinya ada niat untuk menjadi guru, mahasiswa hanya menilai bahwa seseorang yang berprofesi sebagai guru itu berarti seseorang telah melakukan perkerjaan yang mulia. Hal ini berarti penilaian seseorang tidak menuntut seseorang tersebut untuk melakukan hal itu, karena penilaian hanya berisis pandangan seseorang. Hal ini sesuai dengan Theory of Planned Behavior (Teori Perilaku Terencana) yang menyatakan bahwa seseorang yang menyatakan setuju terhadap pandangan positif orang lain bukan berarti ia harus melakukan suatu perilaku tersebut.

Persepsi seseorang terhadap profesi guru yang tinggi atau baik belum tentu minat menjadi guru dalam dirinya juga tinggi, karena persepsi tentang profesi guru merupakan pandangan seseorang saja terhadap profesi guru, sehingga persepsi tersebut dapat tidak mempengaruhi minatnya untuk berprofesi sebagai seorang guru.

Hasil penelitian ini sejalan dengan hasil penelitian yang dilakukan oleh Desti dan Rediana (2017) tentang Pengaruh Persepsi Profesi Guru, Lingkungan Keluarga dan Efikasi Diri Terhadap Minat Menjadi Guru dengan hasil yang menunjukkan bahwa secara parsial tidak ada pengaruh 
persepsi profesi guru terhadap minat menjadi guru pada mahasiswa Pendidikan Akuntansi 2014 Fakultas Ekonomi Universitas Negeri Semarang.

\section{Pengaruh Pengenalan Lapangan Persekolahan (PLP) Terhadap Minat Menjadi Guru}

Berdasarkan hasil uji t menunjukkan bahwa nilai thitung sebesar 2,953 > tabel sebesar 2,001 dan nilai signifikasi sebesar 0,005 $<0,05$, maka $\mathrm{H}_{03}$ ditolak dan $\mathrm{H}_{\mathrm{a}}$ diterima. Dari hasil ini dapat disimpulkan bahwa Pengenalan Lapangan Persekolahan (PLP) berpengaruh yang signifikan terhadap minat mnejadi guru pada mahasiswa Prodi Pendidikan Ekonomi Universitas Kanjuruhan Malang angkatan 2016 dan 2017. Koefisien dterminasi parsial menunjukkan nilai 0,362 atau 13,1\%. Artinya Pengenalan Lapangan Persekolahan (PLP) berpengaruh secara parsial sebesar dengan kontribusi $13,1 \%$ terhadap minat menjadi guru.

Pengenalan Lapangan Persekolahan (PLP) merupakan program yang diperuntukkan untuk melatih mahasiswa dalam mengimplementasikan hasil belajar di kampus untuk diterapkan dalam lingkungan yang nyata di lembaga pendidikan atau di sekolah. Dengan adanya kegiatan PLP ini mahasiswa akan dapat memperoleh pengalaman untuk menjadi seorang guru di lingkungan sekolah. Dari pengalaman ini akan menimbulkan minat bagi mahasiswa tersebut untuk menjadi seorang guru.

Pengalaman adalah salah satu faktor intrinsik yang dapat mempengaruhi minat seseorang untuk menjadi seorang guru, dimana mahasiswa mendapatakan pengalaman melalui program Pengenalan Lapangan Persekolahan (PLP). Pengalaman yang baik (positif )akan meningkatkan minat mahasiswa untuk menjadi seorang guru. Hubungan mahasiswa dengan lingkungan sekolah tempat ia melaksanakan PLP baik dengan pihak guru maupun peserta didik yang terjalin dengan baik dan adanya saling menghormati antara mahasiswa dengan warga lingkungan sekolah, maka dari hal ini terjalinnya hubungan baik yang mampu mempengaruhi minat mahasiswa untuk menjadi seorang guru. Hal ini sesuai dengan pendapat Sardiman (2012:89-91) yang menyatakan bahwa salah satu faktor intrinsik yang dapat mempengaruhi minat adalah pengalaman, dimana pengalaman mahasiswa mengikuti program Pengenalan Lapangan Persekolahan (PLP).

Pengenalan Lapangan Persekolahan (PLP) disini memiliki arti penting dan mempunyai kegunaan yang besar bagi pengalaman yang diperoleh mahasiswa. Dengan adanya PLP ini mahasiswa dapat merasakan langsung berada di tengah-tengah lingkungan sekolah yang nantinya akan dihadapi ketika mahasiswa menjadi seorang guru. Dari hal ini, pengalaman yang dirasakan mahasiswa akan mendorong minat mahasiswa untuk menjadi seorang guru. Oleh karena itu, Pengenalan Lapangan Persekolahan (PLP) memiliki pengaruh yang signifikan terhadap minat mahasiswa untuk menjadi seorang guru.

Hal ini sejalan dengan penelitian yang dilakukan oleh Yayan (2017) tentang Pengaruh Pembelajaran Mikro (Micriteaching) dan Program Pengalaman Lapangan (PPL) Terhadap Minat Mahasiswa Menjadi Guru yang menunjukkan bahwa secara parsial Program Pengalaman Lapangan (PPL) berpengaruh terhadap minat mahasiswa menjadi guru.

\section{Pengaruh Efikasi Diri Terhadap Minat Menjadi Guru}

Berdasarkan hasil uji t menunjukkan bahwa nilai thitung sebesar 3,538 > tabel sebesar 2,001 dan nilai signifikasi sebesar 0,001 $<0,05$, maka $\mathrm{H}_{04}$ ditolak dan $\mathrm{H}_{a 4}$ diterima. Dari hasil ini dapat disimpulkan bahwa efikasi diri berpengaruh yang signifikan terhadap minat mnejadi guru pada mahasiswa Prodi Pendidikan Ekonomi Universitas Kanjuruhan Malang angkatan 2016 dan 2017. Koefisien dterminasi parsial menunjukkan nilai 0,421 atau $17,7 \%$. Artinya Pengenalan Lapangan 
Persekolahan (PLP) berpengaruh secara parsial sebesar dengan kontribusi 17,7\% terhadap minat menjadi guru.

Efikasi diri adalah suatu keyakinan yang dimilki seseorang atas kemampuan yang dimilkinya. Mahasiswa yang memilki efikasi diri yang tinggi berarti mahasiswa memilkik keyakinan bahwa ia mampu menyelesaikan tugas-tugas seorang guru baik secara sederhana maupun rumit, mahasiswa yakin mampu menghadapi dan memecahkan permasalahan yang terjadi, serta yakin akan kemampuannya dalam berbagai tugas guru yang dituntut dalam situasi apapun. Keyakinankeyakinan bahwa mahasiswa mampu untuk menyelesaikan tugas sebagai seorang guru akan dapat meningkatkan minat mahasiswa untuk menjadi seorang guru, karena ia sudah yakin bahwa ia mampu untukmenjalankan tugas sebagai profesi guru.

Efikasi diri merupakan suatu keyakinan seseorang mengenai kemampuan yang dimiliki dalam dirinya untuk menguasai satu hal atau tugas. Adanya efikasi diri yang tinggi menunjukkan adanya keyakinan atas kemampuan yang dimilkik seseorang dalam menjalani suatu tugas dan dapat menguasai suatu hal atau tugas tersebut dengan baik. Sehingga, semakin seseorang memilki efikasi diri yang tinggi, maka seseorang tersebut semakin mempunyai keyakianan dalam dirinya untuk mampu menjalankan suatu tugas dengan baik, begitu juga sebaliknya. Hal ini sesuai teori menurut Ghufron dan Suminta (2014:75-76) yang menyatakan bahwa seseorang yang memepunyai efikasi diri yang tinggi akan percaya bahwa ia mampu unutk melakukan sesuatu yang dapat mengubah kejadian-kejadian di sekitarnya. Dimana kejadian-kejadian tersebut adalah minat mahasiswa menjadi seorang guru.

Hasil penelitian ini sejalan dengan penelitian yang dilakukan oleh Eka (2018) tentang Pengaruh Pengaruh Efikasi Diri dan Persepsi Terhadap Minat Menjadi Guru Ekonomi Pada Mahasiswa Program Studi Pendidikan Ekonomi 2015 UNESA dengan hasil yaitu secara parsial efikasi diri berpengaruh yang signifikan terhadap minat menjadi guru pada mahasiswa.

\section{KESIMPULAN}

Berdasarkan hasil penelitian yang telah dilakukan oleh peneliti mengenai pengaruh persepsi profesi guru, Pengenalan Lapangan Persekolahan (PLP) dan efikasi diri terhadap minat menjadi guru pada mahasiswa Prodi Pendidikan Ekonomi Universitas Kanjuruhan Malang angakatan 2016 dan 2017, maka dapat disimpulkan bahwa secara simultan terdapat pengaruh yang signifikan antara persepsi profesi guru, Pengenalan Lapangan Persekolahan (PLP) dan efikasi diri terhadap minat menjadi guru. Secara parsial persepsi profesi guru tidak berpengaruh terhadap minat menjadi guru. Pengenalan Lapangan Persekolahan (PLP) berpengaruh yang signifikan terhadap minat menjadi guru. Efiaksi diri berpengaruh yang signifikan terhadap minat menjadi guru.

\section{DAFTAR PUSTAKA}

Aini, Eka Nur. 2018. Pengaruh Efikasi Diri dan Persepsi Terhadap Miant Menjadi Guru Ekonomi Pada Mahasiswa Program Studi Pendidikan Ekonomi 2015 UNESA. Jurnal Pendidikan Ekonomi Manajemen Keuangan. (Online), 2 (2): 83-96, diakses 2 November 2018.

Aglazor, Genevieve. 2017. The Role of Teaching Practice in Teacher Education Programmers: Designing Framework for Best Practice. Global Journal Education Research, (Online), 16: 101-110. (http://dx.dol.org/10.4314/gjedr.v1612.4), diakses 8 November 2019.

Ardyani, Anis dan Lyna Latifah. 2014. Analisis Faktor-Faktor yang Mempengaruhi Minat Mahasiswa Menjadi Guru Akuntansi Pada Mahasiswa Prodi Akuntansi Angkatan 2010 Universitas 
Negeri Semarang. Economic Education Analysis Journal Online. (Online), 3 (2): 2014, (http://journal.unnes.ac.id/sju/index.php/eeaj), diakses 30 November 2019.

Ajzen, Icek. 1991. Theory of Planned Behavior. Organizational Behavior and Human Decision Processes50. University of Massachusetts at Amsherst.

Aurah, Catherine M. 2013. The Effects of Self-Efficacy Beliefs and Metacognition on Academic Performance: A Mixed Method Study. American Journal of Education Research, (Online), 1 (8): 334-343, (http://pubs.sciepub.com/education/1/8/11), diakses 8 November 2019.

Bergmark, Ulrika, Stefan Lundstrom, Lena Manderstedt and Annbritt Palo. 2018. Why Become A Teacher? Student Teachers' Perceptions of the Teaching Profession and Motives for Career Choice. Europan Journal of Teacher Education, (Online), (https://doi.org/10.1080/02619768.2018.1448784), diakses 8 November 2019.

Eren, Altay. 2012. Prospective Teachers' Interest in Teaching, Professional Plans about Teaching and Career Choice Satisfaction: A Relevant Framework. Australian J ournal of Education, (Online), 56 (3): 303318, (DOI: 10.1177/000494411205600308), diakses 8 November 2019.

H.J., Nenty, Moyo, Sello dan Phuti, Fuji. 2015. The Effects of Self-Efficacy Beliefs and Metacognition on Academic Performance: A Mixed Method Study. American Journal of Education Research, (Online), 1 (8): 334-343, DOI: (10.12691/education-1-8-11), diakses 8 November 2019.

Hamalik, Oemar. 2011. Proses Belajar Mengajar. Jakarta: PT. Bumi Aksara.

Hidayat, Yayan. 2017. Pengaruh Pembelajaran Mikro (Microteaching) dan Program Pengalaman Lapangan Terhadap Minat Menjadi Guru. (Online). Makasar: Universitas Negeri Makassar. (Online), (http://eprints.unm.ac.id/15190/1/Yayan\%20Hidayat\%201222040035.pdf), diakses 24 Oktober 2019.

Jahja, Yudrik. 2011. Psikologi Perkembangan (Edisi Pertama). Jakarta: Kencana Prenada Media Group.

Ghufron,M.N. \& Suminta, R.R. 2014. Teori-Teori Psikologi. Jogjakarta: Ar-Ruzz Media.

King, Laura A. 2010. Psikologi Umum. (Alih Bahasa: Brian Marwendys). Jakarta: Salemba Humanika.

Kuswana, Wowo Sunaryo. 2011. Taksonomi Berfikir. Bandung: PT. Remaja Rosda Karya.

Lembaga Pengembangan Pembelajaran dan Praktik Lapangan. 2019. Buku Pedoman Pengenalan Lapangan Persekolahan (PLP). Malang: LP3L Universitas Kanjuruhan Malang.

Mulyana, Agus dan Indarto Waluyo. 2016. Pengaruh Persepsi Tentang Profesi Guru dan Informasi Dunia Kerja Terhadap Minat Menjadi Guru Akuntansi. Kajian Pendidikan Akuntansi, (Online), 5 (8), (http://journal.student.uny.ac.id/ojs/index.php/kpai/article/view/5807), diakses 20 Desember 2019.

Mulyasa, E. 2011. Menjadi Guru Profesional. Bandung: Remaja Rosda Karya.

Ormrod., J.E. 2011. Psikologi Pendidikan: Membantu Siswa Tumbuh dan Berkembang Jilid 2. Jakarta: Erlangga.

Peraturan Pemerintah Pendidikan dan Kebudayaan RI No. 87 Tahun 2013 tentang Program Pendidikan Profesi Guru Prajabatan. Menteri Pendidikan dan Kebudayaan Republik 
Indonesia. (Online), (https://kelembagaan.ristekdikti.go.id/wpcontent/uploads/2016/11/permen_tahun2013_nomor87.pdf), diakses 13 Februari 2020.

Sardiman. 2012. Interaksi dan Motivasi Belajar Mengajar. Jakarta: Raja Grafindo Persada.

Sari, Novita, Trisno Martono dan Sri Wahyuni. 2017. Pengaruh Pembelajaran Microteaching dan Program Pengalaman Lapangan (PPL) Terhadap Minat Menjadi Guru Pada Mahasiswa. Jurnal Pendidikan Bisnis dan Ekonomi, (Online), 3 (2). (https://jurnal.uns.ac.id/bise/article/view/16548), di akses 25 Oktober 2019.

Slameto. 2010. Belajar dan Faktor-faktor yang Mempengaruhinya. Jakarta: Rineka Cipta.

Syah, Muhibbin. 2013. Psikologi Pendidikan dengan Pendidikan Baru. Bandung: PT. Remaja Rosda Karya.

Undang-undang Republik Indonesia Nomor 14 Tahun 2005 \& Peraturan Menteri Pendidikan dan Kebudayaan Republik Indonesia Tahun 2014 tentang Guru dan Dosen. 2015. Bandung: Citra Umbara

Wahyu, Prayoga Ramadhan. 2019. Pengaruh Efikasi Diri dan Pengalaman Kajian dan Praktik Lapangan (KPL) Terhadap Minat Menjadi Guru (Studi Pada Mahasiswa Program Studi Pendidikan Administrasi Perkantoran Jurusan Manajemen Fakultas Ekonomi Universitas Negeri Malang). (Online), (http://karyailmiah.um.ac.id/index.php/manajemen/article/view/82981/0), diakses 3 Desember 2019

Wahyuni, Desti dan Redianan Setiyani. 2017. Pengaruh Persepsi Profesi Guru, Lingkungan Keluarga, Efikasi Diri Terhadap Minat Menjadi Guru. Economic Education Analysis Journal, (Online), 6 (3): 669-682, (http://journal.unnes.ac.id/sju/index.php/eeaj). Di akses Oktober 2017.

Wibowo, Mungin Eddy. 2012. Menyiapkan Bangkitnya Generasi Emas Indonesia. Guru Besar Universitas Negeri Semarang. (Online), (https://eprints.umk.ac.id/1042/2/1__Prof._Mungin.pdf), diakses 17 Februari 2020 